\title{
INFLUENCE OF SALT LEVEL, STARTER CULTURE, FERMENTABLE CARBOHYDRATES, AND TEMPERATURE ON THE BEHAVIOUR OF L. MONOCYTOGENES IN SLICED CHOURIÇO DURING STORAGE
}

\author{
J. García-DíEz* and L. Patarata
}

CECAV, Centro de Ciência Animal e Veterinária, Universidade de Trás-os-Montes e Alto Douro, Quinta de Prados, 5000-801, Vila Real. Portugal

(Received: 1 June 2016; accepted: 27 October 2016)

Sliced ready-to-eat traditional meat products presented in individual packaging with more convenience to the consumer is the way that food industry tries to adapt to the new consumer tendencies.

The current work assessed the survival of Listeria monocytogenes in a contaminated sliced vacuum packed chouriço with different sugar concentrations, two salt levels, and presence/absence of Lactobacillus sakei as starter culture along the storage period at two temperatures $\left(8{ }^{\circ} \mathrm{C}\right.$ and $\left.22{ }^{\circ} \mathrm{C}\right)$. Neither the inoculation with $L$. sakei, nor the addition of carbohydrates influenced the survival of the pathogen. Higher amount of salt resulted in a significant reduction of $L$. monocytogenes, and storage at the higher temperature displayed a safer product. After 7 days, $L$. monocytogenes was not detected in any samples. The study of the association of the factors contributing for $L$. monocytogenes survival by logistic regression showed that increasing the level of salt addition from $1.5 \%$ to $3 \%$ reduces the odds of survival of $L$. monocytogenes to about one fifth $(0.174)$. Worthy of attention is the significant reduction in the odds $(\mathrm{OR}=0.028)$ of finding viable $L$. monocytogenes when the samples are stored at room temperature $\left(22^{\circ} \mathrm{C}\right)$, when compared to low temperature $\left(8^{\circ} \mathrm{C}\right)$.

The general and indiscriminate use of refrigeration for meat products might increase the risk of presence of $L$. monocytogenes. The competitive advantage that L. monocytogenes has at low temperatures, as the potential inhibition of LAB activity, is probably the reason of the observed behaviour. The amount of salt was an important hurdle to control L. monocytogenes growth, so, manufacturing meat products with lower salt contents to meet the demands of healthy products might represent a risk for safety, since high levels of salt together with low $\mathrm{a}_{\mathrm{w}}$ are the keys for their conservation.

Keywords: chouriço, sliced, vacuum-packaging, L. monocytogenes, L. sakei, storage

Traditional Portuguese meat products are characterized by a wide number of products of considerable gastronomic, social, and economical importance, the chouriço being the most representative of these meat products (MELo et al., 1991). These kinds of products have a well-founded reputation as safe products. The changes in their composition, mainly in their $\mathrm{pH}$ and water activity $\left(\mathrm{a}_{\mathrm{w}}\right)$, and the presence of salt, nitrites, spices, and other ingredients, are the hurdles that hinder the growth of food-borne pathogens (ORDóÑEZ \& DE LA Hoz, 2007).

Nowadays, consumers demand more ready-to-eat products without added chemical preservatives, low salt levels, or attractive packaging presentations. In consequence, these social changes have conditioned the strategies of meat industry. Thus, the efforts to adapt them, the development of sliced ready-to-eat traditional meat products presented in individual packaging with more convenience to the consumer is a way to adapt to the new consume tendencies. These kinds of food commodities are often presented in vacuum or modified atmosphere packaging and stored at refrigeration temperature, and represent a positive

\footnotetext{
* To whom correspondence should be addressed.

Phone: +351259350000; fax: +351259350480; e-mail: juangarciadiez@gmail.com
} 
economic impact to the meat industry. However, their food safety risks are higher than the traditional products due to the slicing process.

Listeria monocytogenes is a well-known food-borne pathogen of meat industry due to its ubiquity and survival capacity under adverse conditions (GómEz et al., 2014), and responsible for listeriosis disease. In one hand, individuals with a good health status are usually not affected, however, even they can develop listeriosis or listerial gastroenteritis if a large number of $L$. monocytogenes cells are consumed. On the other hand, listeriosis in risk population (pregnant women, new-born infants, children or inmunocompromised individuals) has a severe impact, and it is responsible for abortion, meningitis, or septicemic syndrome (Tham \& DANiElsson-Tham, 2013).

L. monocytogenes can grow at low temperatures, survives at low $\mathrm{a}_{\mathrm{w}}$ and $\mathrm{pH}$ values, and persists for long periods of time in food processing environments due to their biofilm forming ability and resistance to sanitizers (GANDHI \& CHIKINDAS, 2007). Since $L$ monocytogenes is ubiquitous in nature and ready-to-eat products are exposed to the environment during slicing process, L. monocytogenes can easily adhere to the products (MOORE, 2004; PÉREZ-Rodríguez et al., 2010). In consequence, the effect of the several hurdles naturally present in this kind of products (i.e. $\mathrm{pH}, \mathrm{a}_{\mathrm{w}}$ ), the correct implementation of an HACCP system, and pre-requisite programs are the most valuable tools available to ensure the safety of these products (WALLACE \& Williams, 2001).

Safety issues regarding L. monocytogenes in traditional dry-cured meat products during manufacturing have been previously reported (EnCINAS et al., 1999; DíEZ \& PATARATA, 2013), although research on its control in sliced dry-cured meat products is scarce. Thus, the objective of this work was the study of the effects of salt level, L. sakei starter culture, fermentable carbohydrates, and storage temperature in sliced vacuum-packaged chouriço on the behaviour of L. monocytogenes.

\section{Materials and methods}

\subsection{Microorganisms and growth conditions}

Four indigenous strains of L. monocytogenes (Table 1) were previously isolated from chouriço or its production environment, and identified by a species-specific PCR technique (SIMON et al., 1996; TALON et al., 2007).

Table 1. Strains of L. monocytogenes used in the experiment

\begin{tabular}{ll}
\hline Strain & Source \\
\cline { 2 - 2 } NCTC 7973 & National Collection of Type Cultures, Salisbury, UK). \\
EDS-B-LM02 & Chouriço batter \\
JI-Me-LM03 & Meat used in meat products preparation \\
EDS-E-LM02 & Environment of meat products preparation \\
MPI-E-LM01 & Environment of meat products preparation \\
\hline
\end{tabular}

Strains isolated from meat products or environment of its production are from UTAD/LP laboratory collection 
The experiments were conducted with a cocktail composed of the four indigenous strains and one reference strain. The pathogen was grown on brain heart infusion agar (BHI - Biokar, Beauvais, France) and incubated for $24 \mathrm{~h}$ at $30^{\circ} \mathrm{C}$.

To screen the inhibition activity against $L$. monocytogenes, a total of 13 strains of lactic acid bacteria, belonging to the species $L$. sakei, were used in this study. These strains were maintained at $-18{ }^{\circ} \mathrm{C}$. Strains were subcultured twice in Man-Rogosa-Sharpe medium (MRS, Biokar) before use, and were incubated for 18 to 24 hours at $30^{\circ} \mathrm{C}$. Cultures for inoculation were grown individually overnight, harvested by centrifugation, washed twice, and resuspended in $0.85 \% \mathrm{NaCl}$ to obtain an optical density (OD) of $600 \mathrm{~nm}$ of ca. 0.5 .

\subsection{Antagonistic activity against foodborne pathogens}

The agar spot test method (SCHILLINGER \& LUCKE, 1989) was used to determine the antagonism of the LAB activity against the pathogens. Thirteen strains of L. sakei (Table 2) were tested individually against a cocktail of five strains of $L$. monocytogenes.

\begin{tabular}{|c|c|}
\hline L. sakei strain & L. monocytogenes \\
\hline Ls 1320 & ++ \\
\hline Ls 1322 & - \\
\hline Ls 1336 & - \\
\hline Ls 1343 & - \\
\hline Ls 1345 & + \\
\hline Ls 1358 & + \\
\hline Ls 1376 & ++ \\
\hline Ls 1377 & $(+)$ \\
\hline Ls 1378 & - \\
\hline Ls 1382 & - \\
\hline Ls 1394 & - \\
\hline Ls 1305 & $(+)$ \\
\hline ATCC 15521 & - \\
\hline $\begin{array}{l}\text {-: no inhibition } \\
+: \text { inhibition zon } \\
10 \mathrm{~mm} \text {; *: mixt } \\
7973 \text {, EDS-B-- } \\
\text { MPI-E-LM01) }\end{array}$ & $\begin{array}{l}\text { on zone under } 5 \mathrm{~mm} \text {; } \\
\text { inhibition zone over } \\
\text { genes strains (NCTC } \\
\text { 403, EDS-E-LM02, }\end{array}$ \\
\hline
\end{tabular}

A cell suspension in $0.85 \% \mathrm{NaCl}$ of each $L$. sakei strain was dotted $(10 \mu \mathrm{l})$ onto the surface of MRS agar with only $0.2 \%$ glucose (MRS 0.2 ) and was anaerobically incubated for $24 \mathrm{~h}$ at $30^{\circ} \mathrm{C}$. For L. monocytogenes, $100 \mu \mathrm{l}$ of the cell suspension cocktail to be tested for sensitivity (approximately $8 \log \mathrm{CFU} \mathrm{m} \mathrm{m}^{-1}$ ) was inoculated in $7 \mathrm{ml}$ of melted brain heart infusion broth supplemented with $0.7 \%$ agar (brain heart infusion soft agar) and poured over 
the plate on which the producer was grown. After anaerobic incubation for $24 \mathrm{~h}$ at $30{ }^{\circ} \mathrm{C}$, the plates were checked for inhibition zones. The results were recorded as follows: $(-)$, no inhibition zone; (+), inhibition zone under $5 \mathrm{~mm}$; + , inhibition zone over $5 \mathrm{~mm}$; and ++ , inhibition zone over $10 \mathrm{~mm}$. The $\mathrm{pH}$ of the supernatant of the 24-h growth of L. sakei strains in MRS broth with only $0.2 \%$ glucose was recorded. As the pathogens were used in a cocktail of five strains (four indigenous plus one reference strain), the potential cross-inhibition between the strains was previously screened using the agar spot test method described above by replacing MRS 0.2 with brain heart infusion agar for all the possible combinations of the strains of pathogens tested.

\subsection{Manufacturing of chouriço}

To test the influence of the (i) presence or absence of the indigenous L. sakei starter culture, (ii) presence or absence of $0.75 \%$ dextrose plus $0.75 \%$ lactose, and (iii) the level of salt (1.5 or $3 \%$ ), four replicates were conducted for each condition. To screen the effects more efficiently, the chouriço de vinho (hereafter referred as chouriço) was prepared using meat with very low initial contamination, which was obtained by immersing the pork belly in ethanol, burning the surface, and aseptically handling the inner part. All eight batches $(3 \mathrm{~kg}$ each) were manufactured with ground pork belly (15-mm grinder plate; Mainca, Barcelona, Spain), 5\% regional red wine (11\% ethanol, $\mathrm{pH} 3.8), 125 \mathrm{mg} \mathrm{kg}^{-1} \mathrm{NaNO}_{2}, 125 \mathrm{mg} \mathrm{kg} \mathrm{KNO}_{3}$, and the variable ingredients of the batch. The L. sakei starter culture, selected from the 13 strains tested for antagonistic activity, was suspended in $10 \mathrm{ml}$ of $0.85 \% \mathrm{NaCl}$ to achieve an initial concentration of $6 \log \mathrm{CFU} \mathrm{g} \mathrm{g}^{-1}$. The same amount of $0.85 \% \mathrm{NaCl}$ was added to the samples without the starter culture. After mixing (10 min; Mixer RM-35, Mainca), the batter was rested for $24 \mathrm{~h}$ at $4{ }^{\circ} \mathrm{C}$ before stuffing. The chouriços de vinho were then stuffed into natural thin pork gut, tied in a horseshoe shape, and suspended to drain the excess marinade for $4 \mathrm{~h}$ in a drying chamber at $4{ }^{\circ} \mathrm{C}$ with $85 \%$ relative humidity. They were then smoked for 3 $\mathrm{h}$ in a smoking chamber (Thermaxs $100 \mathrm{EC}$, Begarat, Berlin, Germany) with smoke generated from beechwood scraps. The initial temperature of the smoke chamber was $18{ }^{\circ} \mathrm{C}$. From the start of the process, the temperature inside the chouriços de vinho was monitored at 10-min intervals and never exceeded $35^{\circ} \mathrm{C}$. The chouriços de vinho were then dried at $15{ }^{\circ} \mathrm{C}$ in an $85 \%$ relative humidity environment (Aralab Fitoclima, Rio de Mouro, Portugal) for 30 days.

\subsection{Chouriço contamination}

Samples of each finished chouriço batch were aseptically sliced and contaminated with a suspension of L. monocytogenes (mixture of ATCC 7973 and 4 strains) in $0.9 \% \mathrm{NaCl}$ to obtain 10 to $100 \mathrm{CFU} \mathrm{g}^{-1}$ with $0.1 \mathrm{ml}$ dropped onto the surface. Then, slices of chouriço were vacuum packaged and stored at $4{ }^{\circ} \mathrm{C}$ and $22{ }^{\circ} \mathrm{C}$. Microbial analyses were made after $24 \mathrm{~h}, 7$, 15, and 30 days. The detection was carried out as described in ISO 11290-1 (1996) and confirmed by a species-specific PCR technique.

\subsection{Chemical analysis}

The chemical composition was determined according to ISO recommended procedures: moisture (ISO, 1997), total fat (ISO, 1973), protein (Kjeldahl N×6.25) (ISO, 1978), and NaCl (ISO, 2011). Water activity was measured in a Hygroscope DT apparatus with a WA40 cell maintained at $20 \pm 2{ }^{\circ} \mathrm{C}$. The $\mathrm{pH}$ was measured directly in the chouriço itself using a $\mathrm{pH}$ meter (model MicropH 2002, Crison). 


\subsection{Statistical analysis}

The influence of temperature, salt content, presence/absence of $L$. sakei, and presence/ absence of carbohydrates in the presence/absence of $L$. monocytogenes was assessed by chisquare test and by binary logistic regression.

\section{Results and discussion}

The dry-cured Portuguese chouriço prepared in the present study presented an average crude chemical composition of $34.18 \pm 1.51 \%$ moisture, $24.50 \pm 1.72 \%$ protein, $37.36 \pm 1.72 \%$ fat, and $2.46 \pm 0.08 \%$ salt.

The results of presence/absence of $L$. monocytogenes in chouriço influenced by temperature, salt content, presence/absence of $L$. sakei, and presence/absence of carbohydrates are presented in Table 3. Neither the inoculation with $L$. sakei, nor the addition of carbohydrates influenced the survival of L. monocytogenes. On the contrary, higher amount of salt resulted in a significant reduction of the survival of the pathogen and the higher storage temperature resulted in a safer product. After 7 days, L. monocytogenes was not detected in any of the samples.

Table 3. Presence of Listeria monocytogenes* under the effect of study (results expressed \%)

\begin{tabular}{lccc}
\hline & \multicolumn{2}{c}{ L. monocytogenes* } & Chi-square test (P) \\
\cline { 2 - 3 } & Absence & Presence & \\
\hline Temperature $\left({ }^{\circ} \mathrm{C}\right)$ & 69 & 31 & $11.852 ; 0.001$ \\
$\quad{ }^{\circ} \mathrm{C}$ & 100 & 0 & \\
$22{ }^{\circ} \mathrm{C}$ & & & \multirow{2}{*}{$5.236 ; 0.022$} \\
Salt content $(\%)$ & 50 & 50 & \\
$1.5 \%$ & 88 & 12 & $0.582 ; \mathrm{ns}$ \\
$3 \%$ & & & \\
L. sakei & 63 & 37 & \\
Presence & 75 & 25 & $2.327 ; 0.127$ \\
Absence & & & \\
Carbohydrates & 81 & 19 & \\
Presence & 56 & 44 & \\
Absence & & & \\
\hline
\end{tabular}

Ns: not significant; *: mixture of L. monocytogenes strains (NCTC 7973, EDS-B-LM02, JI-Me-LM03, EDS-ELM02, MPI-E-LM01)

To study the association of the factors contributing to L. monocytogenes survival, a binary logistic regression was performed, using the occurrence of the pathogen as the predicted variable and the storage temperature and salt level as predictors. It was observed that increasing the level of salt addition in the formulation of chouriço from $1.5 \%$ to $3 \%$ reduces the odds (Table 4) of survival of $L$. monocytogenes to about the one fifth (0.174). Worthy of attention is the significant reduction in the odds $(\mathrm{OR}=0.028)$ of finding viable 
L. monocytogenes when the samples are stored at room temperature $\left(22^{\circ} \mathrm{C}\right)$, when compared to low temperature $\left(8^{\circ} \mathrm{C}\right.$, reference category). Similar resistance behaviour was reported by BYELASHOV and co-workers (2009) in vacuum packaged pepperoni.

Table 4. Results of the logistic regression model for the presence of L. monocytogenes in sliced chouriço considering the scores PC 1 (temperature $8{ }^{\circ} \mathrm{C}$ ) and PC3 (salt content $1.5 \%$ ) as predictors

\begin{tabular}{lccccc}
\hline Variable & Beta & SE & $p$ & Odds ratio & $95 \%$ CI \\
\hline Temperature $\left({ }^{\circ} \mathrm{C}\right)$ & -3.59 & 1.500 & 0.017 & 0.028 & $0.001-0.520$ \\
Salt content $(\%)$ & -1.74 & 0.845 & 0.039 & 0.174 & $0.033-0.912$ \\
Constant & -0.005 & 0.496 & 0.015 & & \\
\hline
\end{tabular}

SE: standard error; CI: confidence interval

Presence of Listeria monocytogenes in ready-to-eat meat products had been described as a potential risk for consumers (GormLey et al., 2010; KRAMARENKO et al., 2016).

Residual activity presented in the product against $L$. monocytogenes was most efficient during the first 24 hours in chouriço with high salt contents (3\%). However, for the first 7 days of storage, the temperature played an important role in its conservation, since reductions of $L$. monocytogenes counts were higher in chouriço stored at $22^{\circ} \mathrm{C}$. An important reduction of L. monocytogenes in the 7 first days of storage was also reported by MenÉnDEZ and coworkers (2015) in Spanish chorizo vacuum packaged and stored at $20{ }^{\circ} \mathrm{C}$.

The absence of $L$. monocytogenes counts in samples analysed at 15 and 30 days of storage at both temperatures $\left(8{ }^{\circ} \mathrm{C}\right.$ and $\left.22{ }^{\circ} \mathrm{C}\right)$ indicates that the resistance mechanisms of $L$. monocytogenes are not enough to survive in unfavourable environment (GANDHI \& CHIKINDAS, 2007). Several author reported reductions of $L$. monocytogenes counts in dry-cured sausages during the storage period, being greater at lower levels of $\mathrm{pH}$ and $\mathrm{a}_{\mathrm{w}}$ at the same temperature (LiNDQVisT \& LindBlad, 2009; MENÉNDEZ et al., 2015).

Moreover, PORTO-FetT and co-workers (2008) verified that reduction of L. monocytogenes counts were greater in sliced, contaminated meat sausages than batter contamination during the manufacturing process. In contrast, Mena and co-workers (2004) and VITAS and coworkers (2004) reported the presence of L. monocytogenes in sliced dry-cured meat products (including chouriço).

Survival of $L$. monocytogenes during manufacturing of dry-cured chouriço has also been published in the literature. Dízz and Patarata (2013) reported its absence in the finished product. However, the isolation of Listeria spp. by EncinAS and co-workers (1999) in similar chouriço indicates that resistance of $L$. monocytogenes during the drying process (and presence in the finished product) or contamination during the slicing process could compromise the safety of this product if storage conditions are not adequate. This seems to be affirmed by the isolation of $L$. monocytogenes of sliced chouriço at retail level (MENA et al., 2004; VITAS et al., 2004).

Lactobacillus sakei has been reported as a protective culture with antilisterial activity (BARBosa et al., 2014). In our study, L. sake played no significant role in the reduction of $L$. monocytogenes counts, however, its presence in combination with the hurdles of vacuumpackaging and time-temperature could cause competition for micronutrients utilization that might affect L. monocytogenes growth (KRÖCKEL, 2013). 
Commission Regulation (EC) 1441/2007 regarding microbiological criteria for foodstuffs determines that ready-to-eat foods able to support the growth of L. monocytogenes cannot present counts over $100 \mathrm{CFU} \mathrm{g}{ }^{-1}$ after placed on the market during their shelf-life. Our results may be interesting to meat processors, since the application of appropriate salt levels and/or temperature storage may accomplish the legal requirements and guarantee food safety.

\section{Conclusions}

The general and indiscriminating usage of refrigeration for meat products, even when it is not necessary, might increase the risk of presence of $L$. monocytogenes. The competitive advantage that L. monocytogenes has at low temperatures, while LAB activity is suppressed, is probably the reason to the observed behaviour. The amount of salt in the product was revealed to be an important hurdle to control L. monocytogenes growth, however, consumers demand healthy product with low salt content leading producers to use lower amounts of it. However, we are still unsure of the risk that this reduction might represent for the safety of these products, as high levels of salt and consequently low $\mathrm{a}_{\mathrm{w}}$ are the main hurdles for their conservation.

The work was supported by the strategic research project UID/CVT/00772/2013 of the Foundation for Science and Technology (FCT).

\section{References}

Barbosa, M.S., Todorov, S.D., Belguesmia, Y., Choiset, Y., Rabesona, H., Ivanova, I.V., Chobert, J.M., Haertlé, T. \& Franco, B.D.G.M. (2014): Purification and characterization of the bacteriocin produced by Lactobacillus sakei MBSa1 isolated from Brazilian salami. J. Appl. Microbiol., 116, 1195-1208.

Byelashov, O.A., Carlson, B.A., Geornaras, I., Kendall, P.A., Scanga, J.A. \& Sofos, J.N. (2009): Fate of postprocessing inoculated Listeria monocytogenes on vacuum-packaged pepperoni stored at 4,12 or $25^{\circ} \mathrm{C}$. Food Microbiol., 26, 77-81.

Commission Regulation EC (2007): No. 1441/2007 of 5 December 2007 amending Regulation (EC) No 2073/2005 on microbiological criteria for foodstuffs.

DíEz, J.G. \& PAtarata, L. (2013): Behavior of Salmonella spp., Listeria monocytogenes, and Staphylococcus aureus in chouriço de vinho, a dry fermented sausage made from wine-marinated meat. J. Food Prot., 76, 588-594.

Encinas, J.P., SAnZ, J.J., García-LóPez, M.L. \& Otero, A. (1999): Behaviour of Listeria spp. in naturally contaminated chorizo (Spanish fermented sausage). Int. J. Food Microbiol., 46, 167-171.

Gandhi, M. \& Chikindas, M.L. (2007): Listeria: A foodborne pathogen that knows how to survive. Int. J. Food Microbiol., 113, 1-15.

Gómez, D., Azón, E., Marco, N., Carramiñana, J.J., Rota, C., Ariño, A. \& Yangüela, J. (2014): Antimicrobial resistance of Listeria monocytogenes and Listeria innocua from meat products and meat-processing environment. Food Microbiol., 42, 61-65.

Gormley, F.J., Little, C.L., Grant, K.A., De Pinna, E. \& Mclauchlin, J. (2010): The microbiological safety of ready-to-eat specialty meats from markets and specialty food shops: A UK wide study with a focus on Salmonella and Listeria monocytogenes. Food Microbiol, , 27, 243-249.

ISO (1973): Meat and products - Determination of total fat content. International Organization for Standardization, ISO 1443 .

ISO (1978): Meat and meat products - Determination of nitrogen content. International Organization for Standardization, ISO 937. 
ISO (1996): Microbiology of food and animal feeding stuffs - Horizontal methods for the detection and enumeration of Listeria monocytogenes. International Organization for Standardization, ISO 11290-1.

ISO (1997): Meat and meat products - Determination of moisture content (Reference method). International Organization for Standardization, ISO 1442.

ISO (2011): Meat and meat products. Determination of chloride content, part 1: Volhard method. International Organization for Standardization, ISO 1841-1.

Kramarenko, T., Roasto, M., Keto-Timonen, R., Mäesaar, M., Meremäe, K., Kuningas, M., Horman, A. \& Korkeala, H. (2016): Listeria monocytogenes in ready-to-eat vacuum and modified atmosphere packaged meat and fish products of Estonian origin at retail level. Food Control, 67, 48-52.

KRÖCKEL, L. (2013): The role of lactic acid bacteria in safety and flavour development of meat and meat products. -in: Kongo, M. (Ed.) Lactic acid bacteria $-R \& D$ for food, health and livestock purposes. InTech, Croatia, pp. 129-152.

LindQVist, R. \& LindBlad, M. (2009): Inactivation of Escherichia coli, Listeria monocytogenes and Yersinia enterocolitica in fermented sausages during maturation/storage. Int. J. Food Microbiol., 129, 59-67.

Melo, R.S., Palminha, M. \& Santos, C. (1991): Estudo da Salchicharia tradicional de Trás-os-Montes. (Report on the state of traditional meat products of Tras-os-Montes, Portugal). Laboratório Nacional de Engenharia e Tecnologia Industrial. Departamento de tecnologias das industrias alimentares

Mena, C., Almeida, G., Teixeira, P., HogG, T. \& GibBs, P.A. (2004): Incidence of Listeria monocytogenes in different food products commercialized in Portugal. Food Microbiol., 21, 213-216.

Menéndez, R.A., Rendueles, E., Sanz, J.J., Capita, R. \& García-Fernández, C. (2015): Behavior of Listeria monocytogenes in sliced ready-to-eat meat products packaged under vacuum or modified atmosphere conditions. J. Food Protect., 78, 1891-1895.

Moore, J.E. (2004): Gastrointestinal outbreaks associated with fermented meats. Meat Sci., 67, 565-568.

OrdóÑez, J.A. \& DE LA Hoz, L. (2007): Mediterranean products. -in: ToldRÁ, F. (Ed.) Handbook of fermented meat and poultry. Blackwell Publishing, Oxford, pp. 333-348

Pérez-Rodríguez, F., Castro, R., Posada-Izquierdo, G.D., Valero, A., Carrasco, E., García-Gimeno, R.M. \& ZURERA, G. (2010): Evaluation of hygiene practices and microbiological quality of cooked meat products during slicing and handling at retail. Meat Sci., 86, 479-485.

Porto-Fett, A.C.S., Hwang, C.A., Call, J.E., Juneja, V.K., Ingham, S.C., Ingham, B.H. \& Luchansky, J.B. (2008): Viability of multi-strain mixtures of Listeria monocytogenes, Salmonella typhimurium, or Escherichia coli O157:H7 inoculated into the batter or onto the surface of a soudjouk-style fermented semi-dry sausage. Food Microbiol., 25, 793-801.

SChillinger, U. \& LuCKe, F.K. (1989): Antibacterial activity of Lactobacillus sake isolated from meat. Appl. Environ. Microb., 55, 1901-1906.

Simon, M.C., GraY, D.I. \& Cook, N. (1996): DNA extraction and PCR methods for the detection of Listeria monocytogenes in cold-smoked salmon. Appl. Environ. Microb., 62, 822-824.

Talon, R., Lebert, I., Lebert, A., Leroy, S., Garriga, M., Aymerich, T., Drosinos, E.H., Zanardi, E., Ianieri, A., Fraqueza, M.J., Patarata, L. \& Lauková, A. (2007): Traditional dry fermented sausages produced in smallscale processing units in Mediterranean countries and Slovakia. 1: Microbial ecosystems of processing environments. Meat Sci., 77, 570-579.

Tham, W. \& Danielsson-Tham, M.L. (2013): Listeria monocytogenes - Very food-borne bacteria. -in: Tham, W. \& Danielsson-Tham, M.L. (Eds) Food associated pathogens. CRC Press, New York, pp. 124-140.

Vitas, A.I., Aguado, V. \& García-Jalón, I. (2004): Occurrence of Listeria monocytogenes in fresh and processed foods in Navarra (Spain). Int. J. Food Microbiol., 90, 349-356.

Wallace, C. \& Williams, T. (2001): Pre-requisites: a help or a hindrance to HACCP? Food Control, 12, 235-240. 